\title{
Geotechnical Characteristics of Anhydrite/Gypsum Transformation in the Middle Miocene Evaporites, Red Sea Coast, Egypt
}

\author{
El-Sayed Sedek Abu Seif
}

Received: 23 July 2012 / Accepted: 15 December 2012 / Published online: 3 November 2013

(C) The Author(s) 2013. This article is published with open access at Springerlink.com

\begin{abstract}
The Middle Miocene evaporites of Abu Dabbab Formation, north of Quseir City along the Red Sea coast of Egypt are composed mainly of thinly laminated, bedded and nodular anhydrite and microcrystalline gypsum especially in its lowermost part. Highly cracked inter-bedded clay, dolomite and stromatolite layers were recorded within the evaporite succession. The cracks in the inter-bedded clays are filled with evaporite materials indicating arid climatic conditions during exposure episodes. Swelling mechanisms in clay-evaporites include mechanical swelling due to hydration of clay minerals and transformation of the anhydrite into gypsum. Field observations as well as powder x-ray diffraction investigations have shown that anhydrite/gypsum modal ratio decreases gradually downward indicating that gypsum has transformed to anhydrite by solar heating. The clay minerals of the inter-bedded clay layers are dominated by smectite $(46 \%)$, illite-smectite mixed-layer (18\%), chlorite (13\%), palygorskite ( $9 \%$ ), kaolinite ( $8 \%$ ), and illite (6\%). The liquid limit of the Abu Dabbab Formation (anhydrite and interbedded clays) is higher than $65 \%$, so considered as of very high swelling capabilities. Also, its swelling percentage was found to be (11-14\%), (28-35\%) and (58-65\%) for gypsum, clay and anhydrite, respectively. The swelling pressure was found to be $\left(1.4-1.5 \mathrm{~kg} / \mathrm{cm}^{2}\right),\left(2.3-3.1 \mathrm{~kg} / \mathrm{cm}^{2}\right)$ and $(4.7-$ $5.1 \mathrm{~kg} / \mathrm{cm}^{2}$ ) for gypsum, anhydrite and inter-bedded clay. The swelling pressure of gypsum is moderate and for both
\end{abstract}

E.-S. S. Abu Seif $(\bowtie)$

Faculty of Earth Sciences, King Abdul-Aziz University,

P.O. Box 80206, Jeddah 21589, Saudi Arabia

e-mail: elsayed_71@Yahoo.com

E.-S. S. Abu Seif

Geology Department, Faculty of Science,

Sohag University, P.O. Box 82524,

Sohâg, Egypt anhydrite and clay is high. The highly swelling capability of anhydrite and the inter-bedded clays causes geotechnical problems when got into contact with water. Alternating volume change due to phase transformation and solubility of calcium sulfate adds to the severity of problems associated with the host expansive clay strata.

Keywords Anhydrite/gypsum · Clay · Swelling · Abu Dabbab evaporite

تتكون متبخرات الميوسين الأوسط التابعة لمكون أبو دباب والواقعة المئة

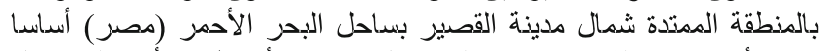

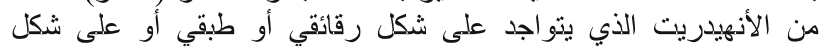

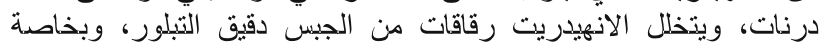

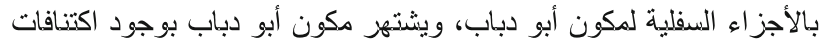

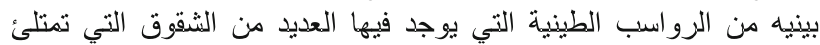

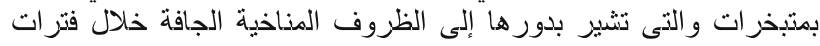

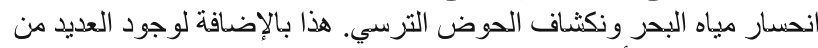
الاكتنافات بمكون أبو دباب من الدلوميت وراقاقات من الثترماتوليت.

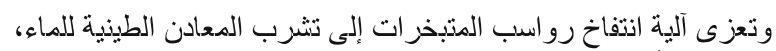

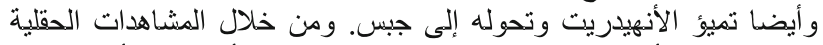

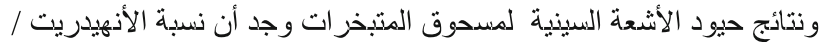

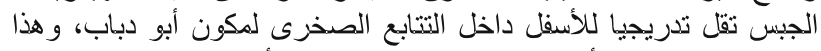

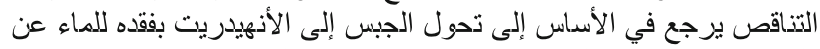

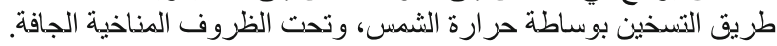

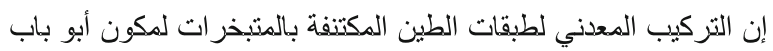

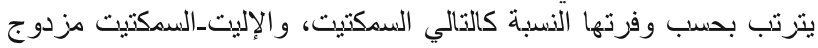
الطبقة، والكلوريت، و البالوجورسكيت، الكاولينيت و الإليت.

ومن خلال التجاب المعملية لرواسب المتبخرات و المكتنفات الطينية لها

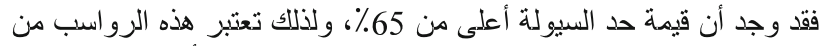

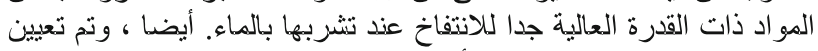

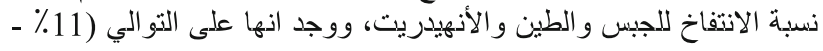


14\%)، (28\% -35٪) و (58\% -65\%). و وكذلك ضغط الانتفاخ للجبس وجد

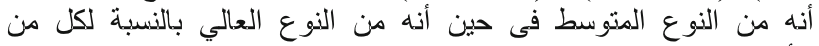

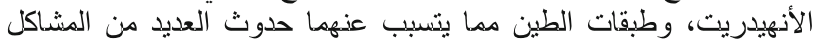

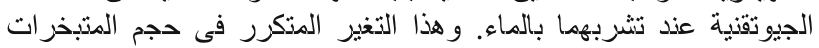

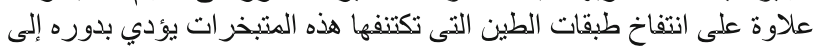
زيادة حدة هذه المثاكل الجيوتقنية.

\section{Introduction}

The Egyptian Red Sea coastal region is characterized by an extreme degree of aridity, high ambient temperature and fluctuating relative humidity. The rainfall is scanty and sporadic and it is usual for the region to go for several successive months without any precipitation. The average rainfall ranges from $<10-15 \mathrm{~mm} /$ year over the sea to a few millimeters per year along the coastline [1]. There is a remarkable variability in daily temperature between the northern and southern Red Sea coastal region. In the north, the maximum daily temperatures range from a low of $20^{\circ} \mathrm{C}$ in January to a high of $35^{\circ} \mathrm{C}$ in July whereas in the south the corresponding range is $29-40{ }^{\circ} \mathrm{C}$ [2]. The hot and arid climate and the saline environment that governs the geological development can influence the engineering behavior of local sedimentary soils [3]. The hydration-dehydration reactions, for example, can alter the crystalline structure of the resulting mineral. Anhydrite has an orthorhombic structure in which $\mathrm{Ca}^{2+}$ is surrounded by eight neighboring $\mathrm{SO}_{4}^{2-}$ ions, whereas the monoclinic structure of gypsum is held by weak hydrogen bonds between water molecules and $\mathrm{SO}_{4}^{2-}$ [4]. These molecular variations mean that estimates of volume change associated with mineral transformation must be on molar volumes of gypsum, anhydrite, and water [5]. Gypsum dehydrated when: (1) exposed at the surface to hot and dry conditions [6], (2) subjected to reaction with brines [7], (3) involved in burial diagenesis [8], and (4) affected by tectonic stresses [9]. Dehydration started at the surface and extended downwards for up to $1,500 \mathrm{~m} \mathrm{[10].}$

The highly swelling capability of anhydrite can only appear when it gets into contact with water. Anhydrite converts to gypsum when inundated with water as the $\mathrm{SO}_{4}^{2-}$ ion attracts the $\mathrm{H}_{2} \mathrm{O}$ molecules because of the polar nature of the latter. The hydration of anhydrite produces a theoretic swelling of up to about $60 \%$ [10-15].

The gypsum/anhydrite transformation was recorded in many parts of the World for examples, (1) Middle Miocene evaporite in southern Poland [16], (2) evaporite succession in the Eastern Province of Saudi Arabia [17], (3) Messinian evaporites of central Tuscany, Italy [18], (4) Middle Triassic evaporites in south Germany and north Switzerland, Gypsum Keuper [19], and (5) in the Arabian Gulf coastal deposits [3].

The Egyptian Red Sea coastal region has undergone development activities such as urbanization, coastal development, tourism, coastal mining and quarrying activities. The construction in the coastal regions may face some obstacles. The soil inferior engineering properties, especially volume increase associated with mineral transition, do not match the heavy loads exerted by the huge projects. Unexpected construction and post-construction problems may arise in some of these projects. This type of problematic soil is considered as one of the obstacles that may face the development plans in this region. A lot of researchers have been conducted on stratigraphical and sedimentolgical characteristics of Abu Dabbab Evaporites, yet little information exits in the literature on their geotechnical properties. In particular there is little guidance available for practicing engineers on how to choose design parameters, especially for problems related to compression and strength. The objective of this paper is to study the mineralogical composition and the engineering geological aspects of the Abu Dabbab Evaporite section. Such information is essential for urban planers, engineers, and designers to recommend the most appropriate type and method of construction to ensure the stability of a structure in its natural setting.

\section{Geological Setting of the Study Area}

The Egyptian Red Sea coastal region can be divided into two structural provinces: the Nubian Shield rocks in the west and the coastal region in the east. The Nubian Shield rocks are ancient land masses that occur as belts parallel to the Red Sea coast and sloping gently towards the Red Sea. It consists of Precambrian basement of gneiss, metamorphic terrestrial sediments, volcanic rocks of the green schist facies, and countless granitoid plutonic bodies. In some places, the ground elevation is close to the sea level so that tidal changes cause the waterfront to shift back and forth up to hundreds of meters. Sabkha (salt flats) are common all along the coast. The rocks of the coastal region are represented by continental and shallow marine sediments of Neogene age. Arid climatic conditions and restricted lagoonal environment led to the formation of expansive evaporitic succession in the Egyptian Red Sea. This marks the closure of the Red Sea basin during Middle Miocene. The Middle Miocene evaporite sequence of the Abu Dabbab Formation unconformably overlies the older syn-rift and pre-rift strata (Fig. 1). The lateral variation of the Abu Dabbab Evaporites is mainly controlled by structural and topographic elements, including relay ramps between interacting normal fault segments, cross-trend transfer faults, reactivated Precambrian basement and the plunge directions of tilted fault blocks [20]. The inter-bedded clayey layers are formed during marine regression under these arid climatic conditions.

The stratigraphy of the Neogene sediments was studied by many authors [21-27]. [24] subdivided the Neogene sed- 
Fig. 1 Geological map of the study area

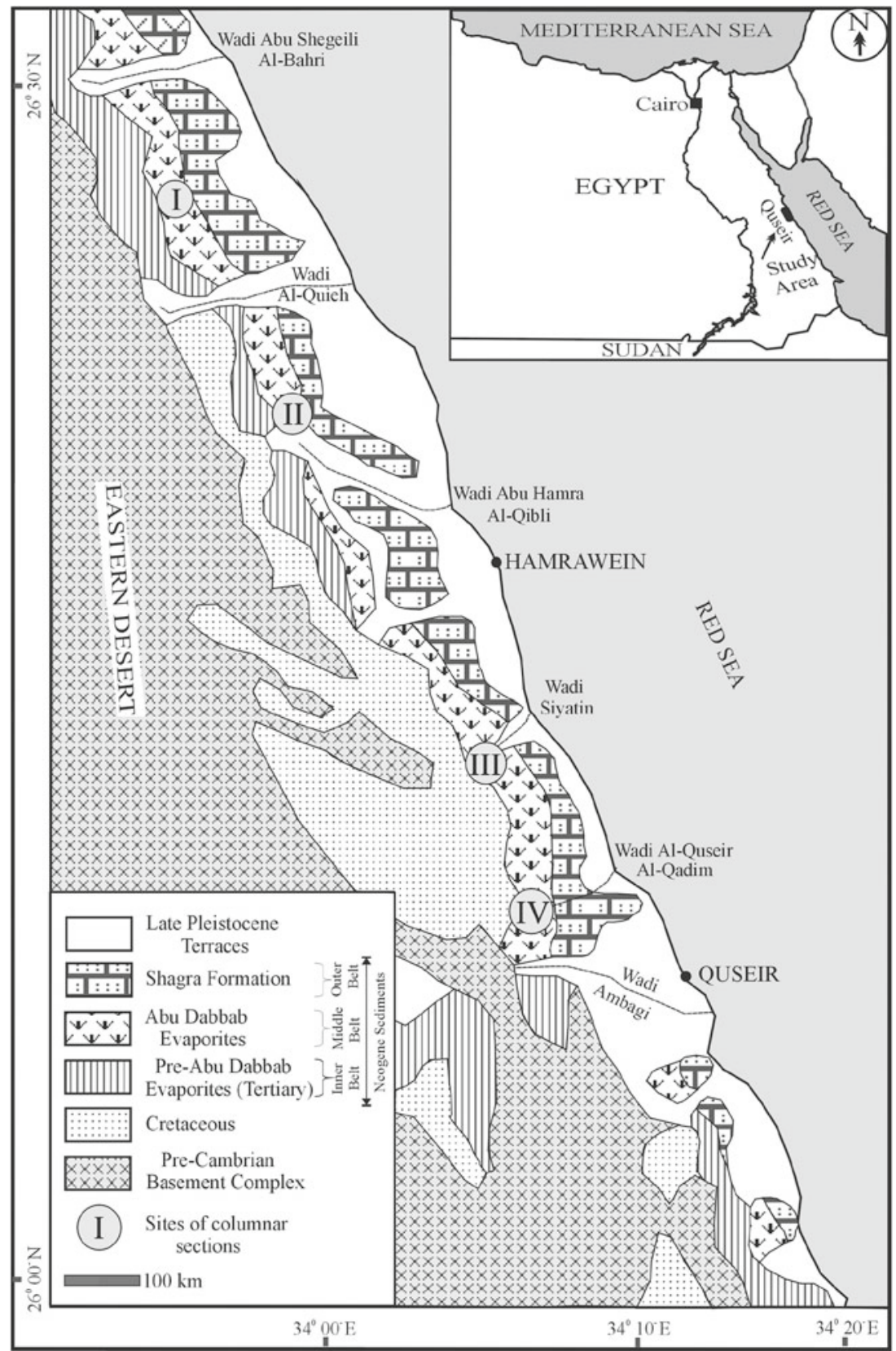

iments that exposed along the Egyptian Red Sea Coast into three belts run parallel to the Red Sea Coast. The inner belt includes clastic rocks (Ranga Formation) and mixed clastic-carbonate rocks (Um Mahara Formation). The middle belt includes fine siliciclastic sediments (Syiatin Formation), Abu Dabbab Evaporite and carbonate rocks (Um Gheig Formation). The outer belt includes the siliciclastic Mersa Alam Formation and the mixed clastic-carbonate Shagra Formation.

The evaporite deposits are of wide spatial distribution in the Neogene sediments. They extend from Jabal El Zeit (90 km south Suez) to Ras Banas (90 km south Marsa Alam) and extend further southward inside the Sudanese land. The
Middle Miocene evaporite represents the main evaporite unit in the Egyptian Red Sea coast. The Abu Dabbab Evaporite is the most famous one, which is characterized by yellowish white to dark grey colour and is easily identified in both field and satellite images. Nonetheless, relatively widespread outcrops can be found close to the present Red Sea Shoreline.

\section{Experimental Tests}

Twenty-three disturbed and undisturbed samples were collected from four selected sites of the Abu Dabbab Formation. 
The samples represent natural evaporites (anhydrite and gypsum) and inter-bedded clays. Water content in the evaporites (gypsum and anhydrite) and clay was determined by heating up to 300 and $110^{\circ} \mathrm{C}$, respectively, for $24 \mathrm{~h}$ according to [28]. Specific gravity was determined according to [29]. Similarly, the liquid limit (LL) and plastic limit (PL) (pulverized pass ASTM Sieve No. $40(0.425 \mathrm{~mm})$ were determined according to [30]. The laboratory tests were designed to investigate the swelling behavior of the evaporite (anhydrite and gypsum) as well as the inter-bedded expansive clayey samples using odeometer testing [31]. The free swell test was carried out as described by [32]. Mineral identification, using x-ray diffraction techniques, has been carried out on selected samples of anhydrite, gypsum and clay. X-ray diffraction analyses for clay samples were performed on the $<2 \mathrm{~mm}$ fraction, which was separated by standard pipette sedimentation technique. The identification of the clay minerals is based on the basal reflections (001), according to the $\mathrm{x}$-ray powder diffraction results of many authors [33-38] and the ASTM cards. Table (1) summarizes the physical, mineralogical and geotechnical properties of the various anhydrite, gypsum and inter-bedded clay of Abu Dabbab Evaporite.

\section{Results and Discussion}

\subsection{Anhydrite/Gypsum Transformation}

Rocks containing clay minerals and anhydrite exhibit the property of volume increase caused by water absorption. This phenomenon is called rock swelling. It is well known that swelling in anhydrite is of a chemical nature and depends on the transformation of anhydrite into gypsum [13]. Mineral transition in the $\mathrm{CaSO}_{4} \cdot 2 \mathrm{H}_{2} \mathrm{O}$ system takes place according to the following reversible hydration-dehydration reaction [39]:

$$
\begin{aligned}
\mathrm{CaSO}_{4} \cdot 2 \mathrm{H}_{2} \mathrm{O} \text { (gypsum) } \longleftrightarrow & \mathrm{CaSO}_{4} \text { (anhydrite) } \\
& +2 \mathrm{H}_{2} \mathrm{O}
\end{aligned}
$$

Anhydrite precipitated as primary mineral in highly alkaline environments and at concentration five times that of seawater [7]. In contrast, gypsum precipitated as primary mineral in shallow evaporitic basins at a three-fold increase in seawater salinity [40]. Gypsum is the most abundant calcium sulphate minerals that form under normal sedimentary conditions [18]. However, anhydrite forms rarely at the surface under certain conditions (e.g. arid hot supratidal environments) [40-43]. Gypsum is the stable form of calcium sulphate in surface conditions and thus predominates in the outcrops except under arid climatic conditions (either cold or hot) where anhydrites appears at the surface $[44,45]$. The anhydrite deposits are formed from both syn-depositional growth and anhydritization of gypsum during early diagenesis [46]. Moreover, gypsum is readily transformed to anhydrite and water when heated to a temperature that is a function of salinity of the coexisting fluids. In this respect, [27] pointed out that the anhydrite of Abu Dabbab Evaporites in NW Red Sea has an epigenetic origin during several cycles of hydration and dehydration.

The thickness of Abu Dabbab Evaporites is about $45 \mathrm{~m}$ at Site I (Wadi Al-Quieh), $55 \mathrm{~m}$ at site II (Wadi Abu Hamra Al-Qibli), $110 \mathrm{~m}$ at site III (Wadi Siyatin) and $85 \mathrm{~m}$ at site IV (Wadi Al-Qusier Al Qadim), (Fig. 2). Field investigations indicated that the Abu Dabbab Evaporite consists mainly of bedded and thinly laminated and nodular evaporites (Fig. 3), which are capped by anhydrite and graded downward into gypsum. Mineral identification by powder x-ray diffraction analysis indicate that the evaporite cap samples are mainly composed of anhydrite (88-97\%) with subordinate gypsum (3-12\%), while samples from the lowermost part near the ground surface is consisting of gypsum (87-89\%) and anhydrite (11-13\%), (Table 1; Fig. 4).

The presence of dolomite layers within the Abu Dabbab Evaporite succession (Fig. 2) may indicate that the entire succession was formed by diagenetic processes. In such case, the possible mechanism by which gypsum and anhydrite have evolved is by extensive dolomitization of calcareous interbedded mudstone [47]. However, the inter-bedded mudstone contains aragonite and high-Mg calcite as predominant components and neither of these minerals is diagenetically stable outside the marine environment $[48,49] . \mathrm{Mg}^{2+}$ replaces some of the $\mathrm{Ca}^{2+}$ in the crystal lattice of aragonite. The displaced $\mathrm{Ca}^{2+}$ combines with $\mathrm{SO}_{4}^{2-}$ present in the sea water to precipitate as individual crystals of anhydrite and/or gypsum [47]. Therefore, the anhydrite cap in the Abu Dabbab Evaporite section that ranges in thickness from few meters to tens of meters was most probably formed through transformation processes of gypsum into anhydrite by subaerial weathering and solar hearting in hot arid climate according to the following reaction:

$$
\begin{aligned}
& \mathrm{CaSO}_{4} \cdot 2 \mathrm{H}_{2} \mathrm{O} \text { (gypsum) } \stackrel{\text { Arid condition }+ \text { Solar heating }}{\longrightarrow} \\
& \mathrm{CaSO}_{4} \text { (anhydrite) }+2 \mathrm{H}_{2} \mathrm{O}
\end{aligned}
$$

\subsection{Mineralogical Composition of Inter-Bedded Clays}

The clayey sediments that occur as inter-bedded layers within the evaporite succession are greenish to gray in colour and are highly desiccated and cracked. The cracks are filled with evaporite materials (Fig. 5) that may indicate exposure episodes during marine regression under arid climatic conditions. These evaporitic materials are composed mainly of 


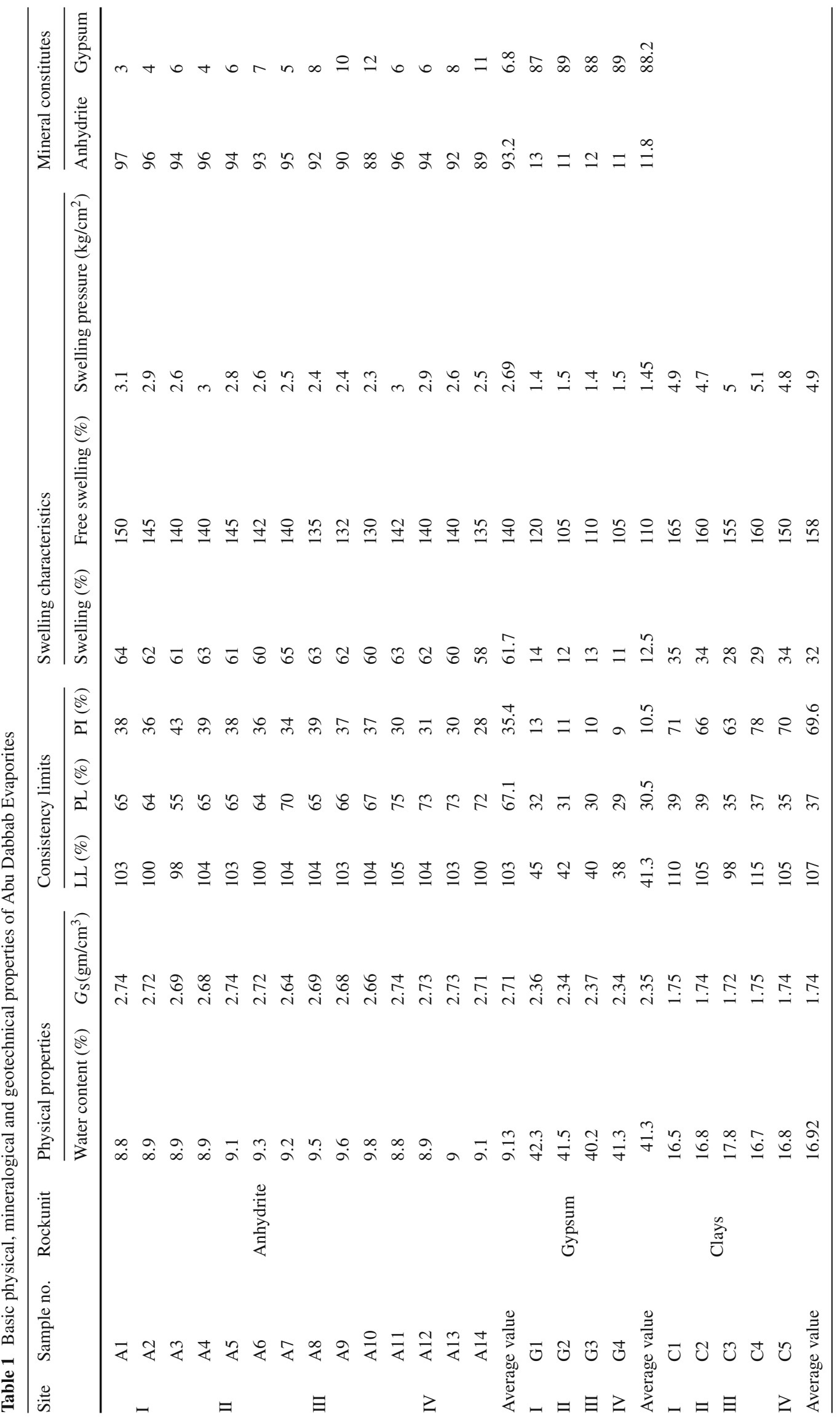

I Springer 


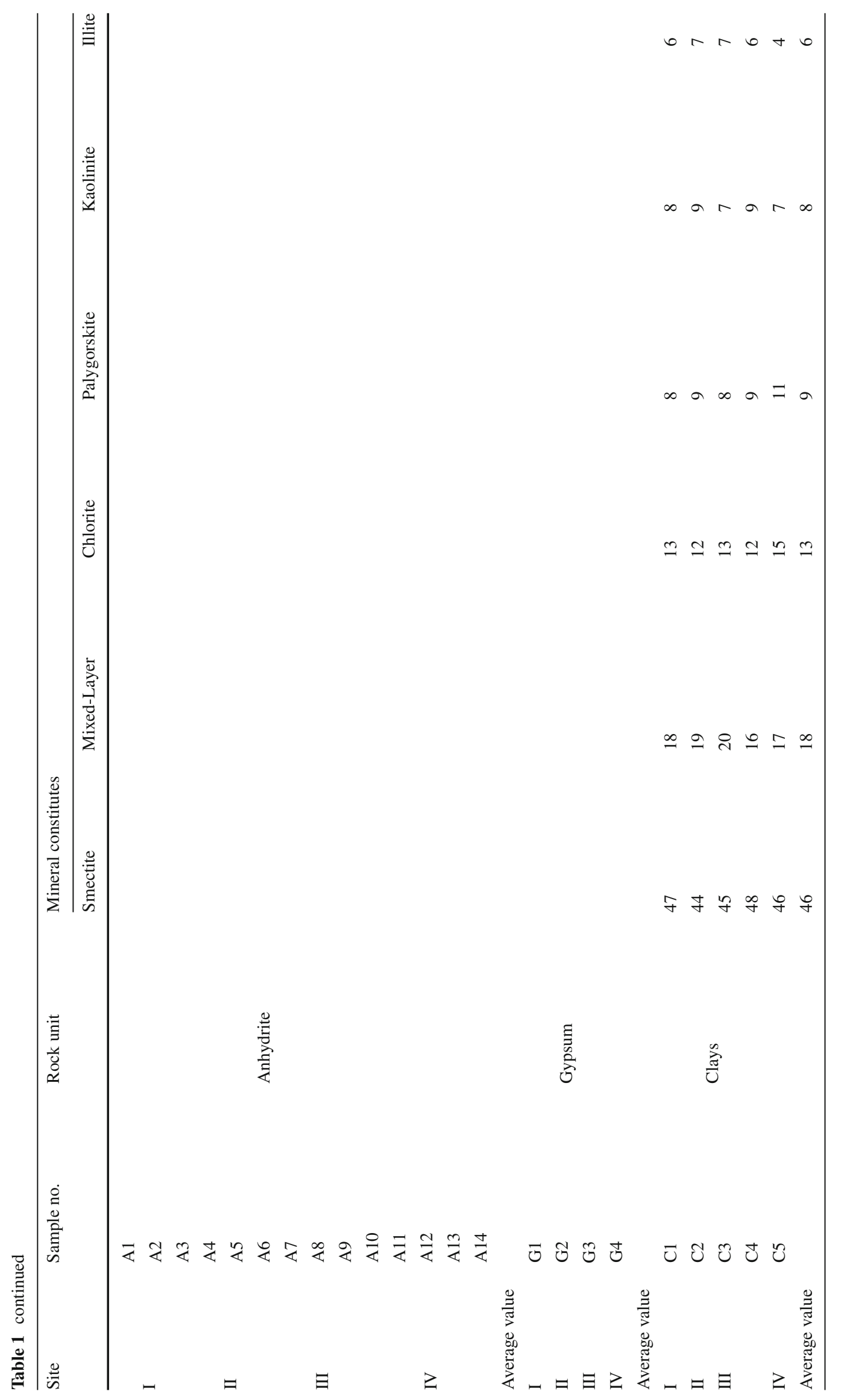

I 
Fig. 2 Columnar sections and sampling numbers of $\mathrm{Abu}$ Dabbab Evaporites in the study area
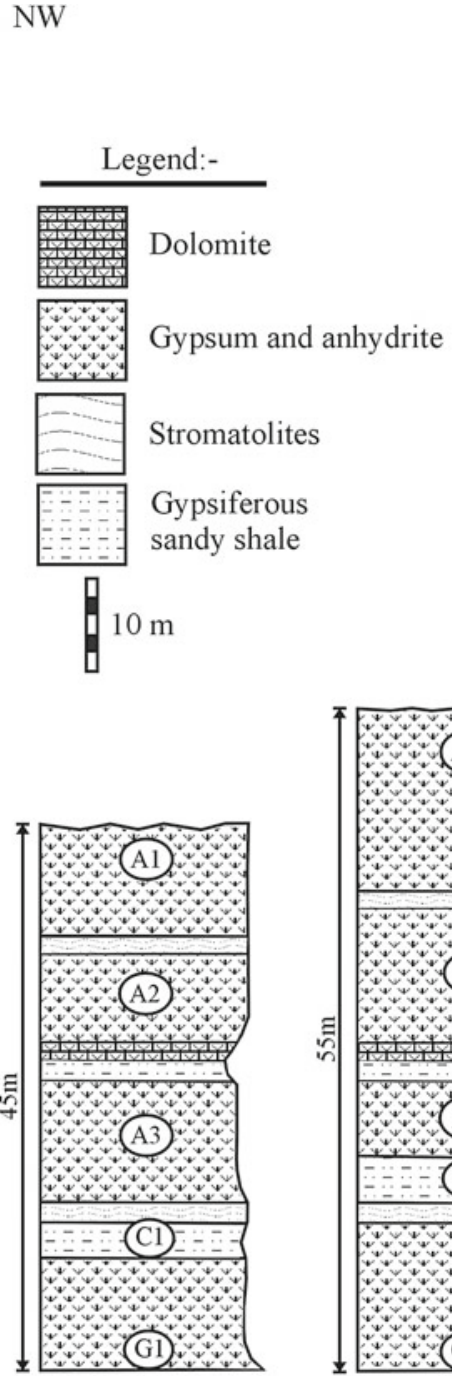

Wadi Al-Quieh (I)

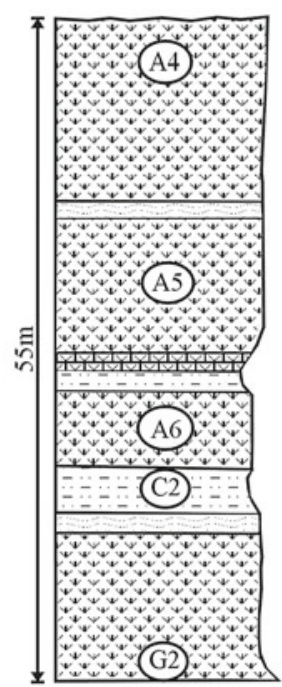

Wadi Abu Hamra Al-Qibli (II)

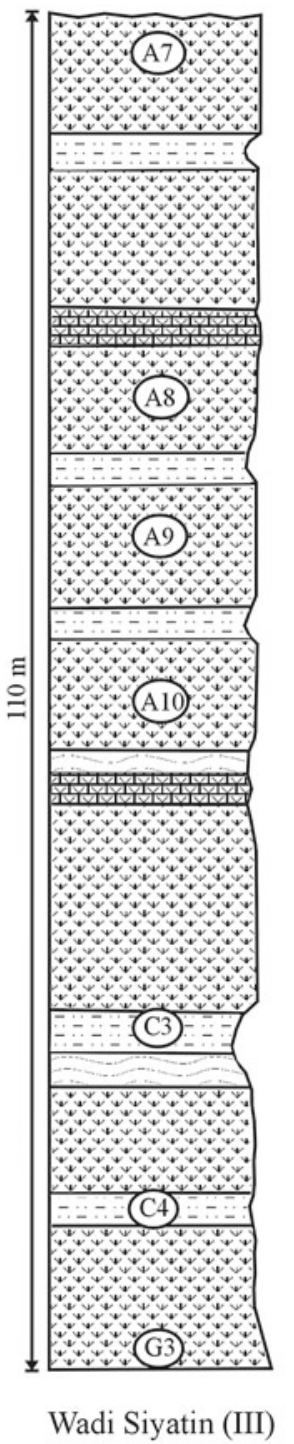

satin spar gypsum under effect of successive cycles of hydration and dehydration [50].

The obtained x-ray diffraction charts were used for identification and quantification of clay mineral. Six types of clay minerals were identified throughout the studied sequence of which smectite is the predominant clay mineral in all samples $(46 \%)$ followed by illite-smectite mixed-layer $(18 \%)$, chlorite $(13 \%)$, palygorskite $(9 \%)$, kaolinite $(8 \%)$, and illite (6\%), (Table 1; Fig. 6a, b).

The clay mineralogy of the inter-bedded clayey layers gives important information about the paleoenvironmental aspects of this evaporitic succession. Except palygorskite, it is believed that most of the clay minerals are detrital in origin. The source of the smectite group minerals of the studied area is volcanic rocks which are abundant in the Nubian Shield rocks and clay-rich units (Pre-Abu Dabbab Formation especially Cretaceous rock units and Siyatin Formation Fig. 1).
Usually the source of smectite group clays is volcanic and metamorphic rocks [51]. Illite, in the study area was derived from schists of Nubian Shield rocks. The diagenetic changes of clay controlled by burial effects usually do not occur in sedimentary series thinner than 2-3 km [52].

Palygorskite is common in the Middle Miocene clastic sediments of the underlying intertidal-lagoonal Siyatin Formation, an environment suitable for the neoformation of palygorskite [53]. Natural occurrences of palygorskite in sediments and soils of arid regions have been widely reported [54,55]. Tertiary sediments appear to be the main host of palygorskite in the Middle East [37,54-56]. [51] has shown that palygorskite derives from chemical precipitation in evaporative basins. He summarized the conditions for palygorskite formation as alkaline conditions in restricted basins subject to marine transgression, limited water exchange, warm and humidity, contrasted climate and strong evapora- 


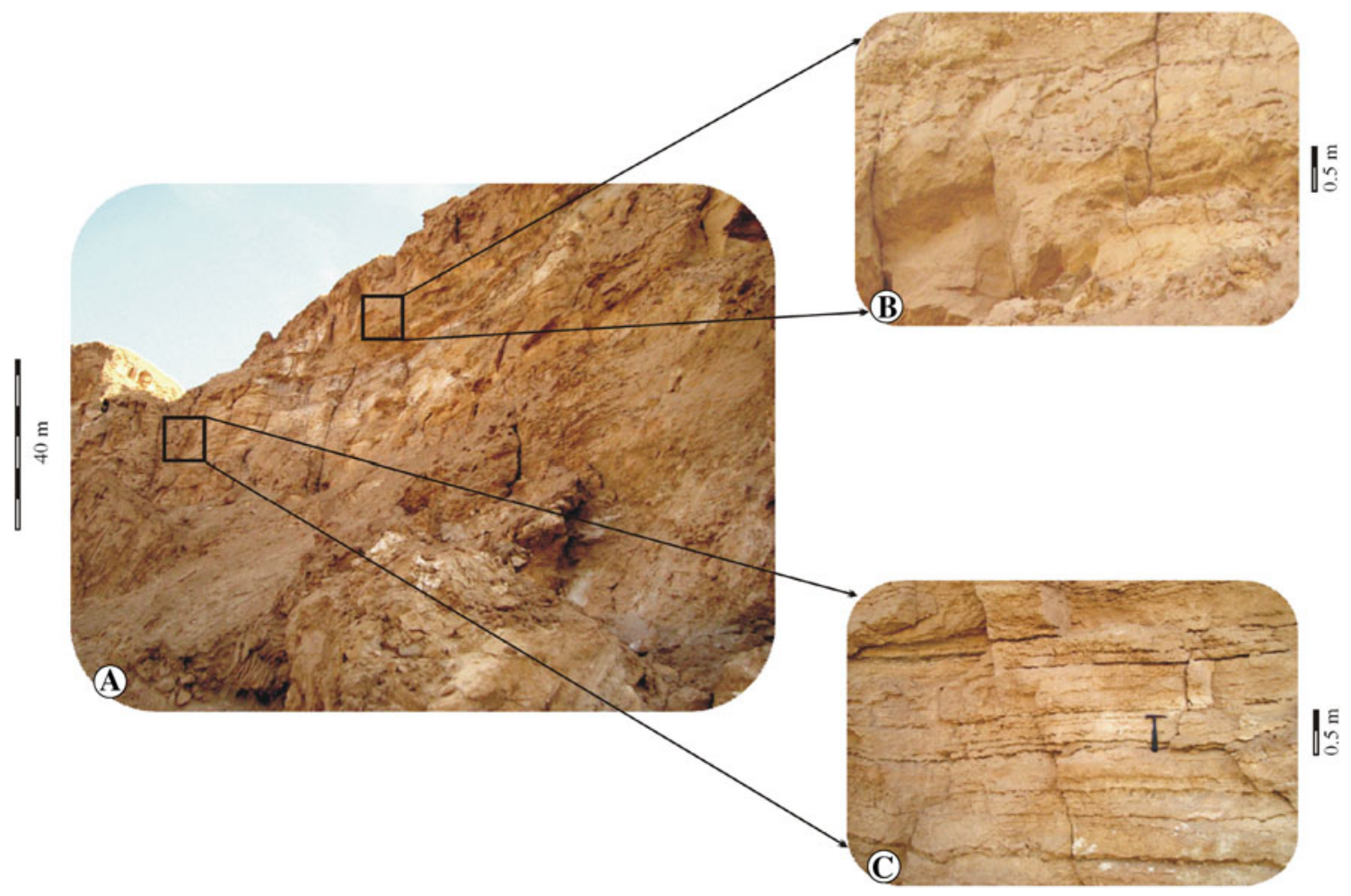

Fig. 3 a General view of Abu Dabbab Evaporites at Wadi Siyatin (16 km north Quseir), b bedded anhydrite, $\mathbf{c}$ Thinly bedded anhydrite

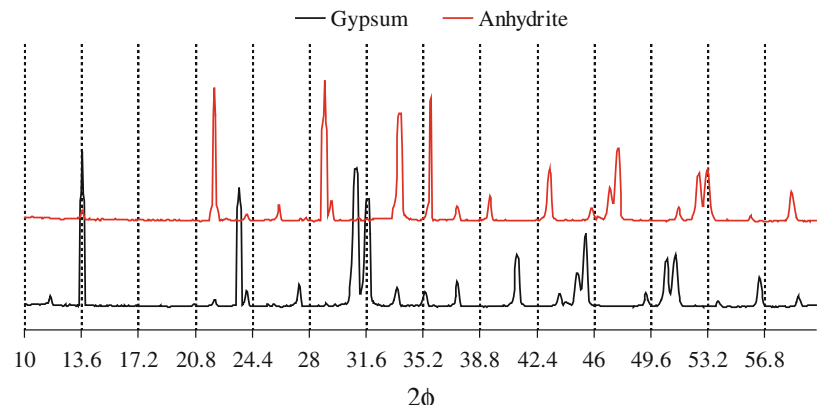

Fig. 4 X-ray diffraction pattern of anhydrite and gypsum samples of Abu Dabbab Evaporite

tion. It seems that these conditions are suitable for the formation of palygorskite as neoformed clay mineral in restricted back-reef and lagoons of the evaporite beds of the Abu Dabbab Formation.

\subsection{Water Content}

An expansive soil tends to swell when there is an increase in its water content. If the soil is confined, it may exhibit considerable swelling pressure. The latter depends on the nature of expansive soil, type of structure and environmental conditions. The water content (moisture or structural) of the studied evaporites (gypsum and anhydrite) and inter-bedded clays play a vital rule in their swelling capability. As shown in Table 1, the water contents of the studied samples vary from 8.8 to $9.8 \%$ in anhydrite, from 16.5 to $17.8 \%$ in clay and from 40.2 to $42.3 \%$ in gypsum. The high water content in gypsum samples relative to those of anhydrite is mainly due to the structural water molecules in gypsum.

\subsection{Specific Gravity}

Table (1) presents the specific gravity data of the studied evaporite and clay samples as follows: anhydrite (from 2.64 to $2.74 \mathrm{gm} / \mathrm{cm}^{3}$ ), gypsum (from 2.34 to $2.37 \mathrm{gm} / \mathrm{cm}^{3}$ ) and clay (from 1.72 to $1.75 \mathrm{gm} / \mathrm{cm}^{3}$ ). It can be seen from these data that the specific gravity of the field samples increases as the amount of calcium sulphate increase. It is also noticed that the specific gravity of the studied samples increases with decreasing water content.

\subsection{Consistency Limits}

Consistency limits are fundamental properties that extensively used in soil classification and to predict their engineering behavior such as swelling and compressibility. The plasticity index (PI) is a measure of the potential plasticity of soil and is widely used in the geotechnical community to assess shrink-swell potential. Soils with high PI-value are 


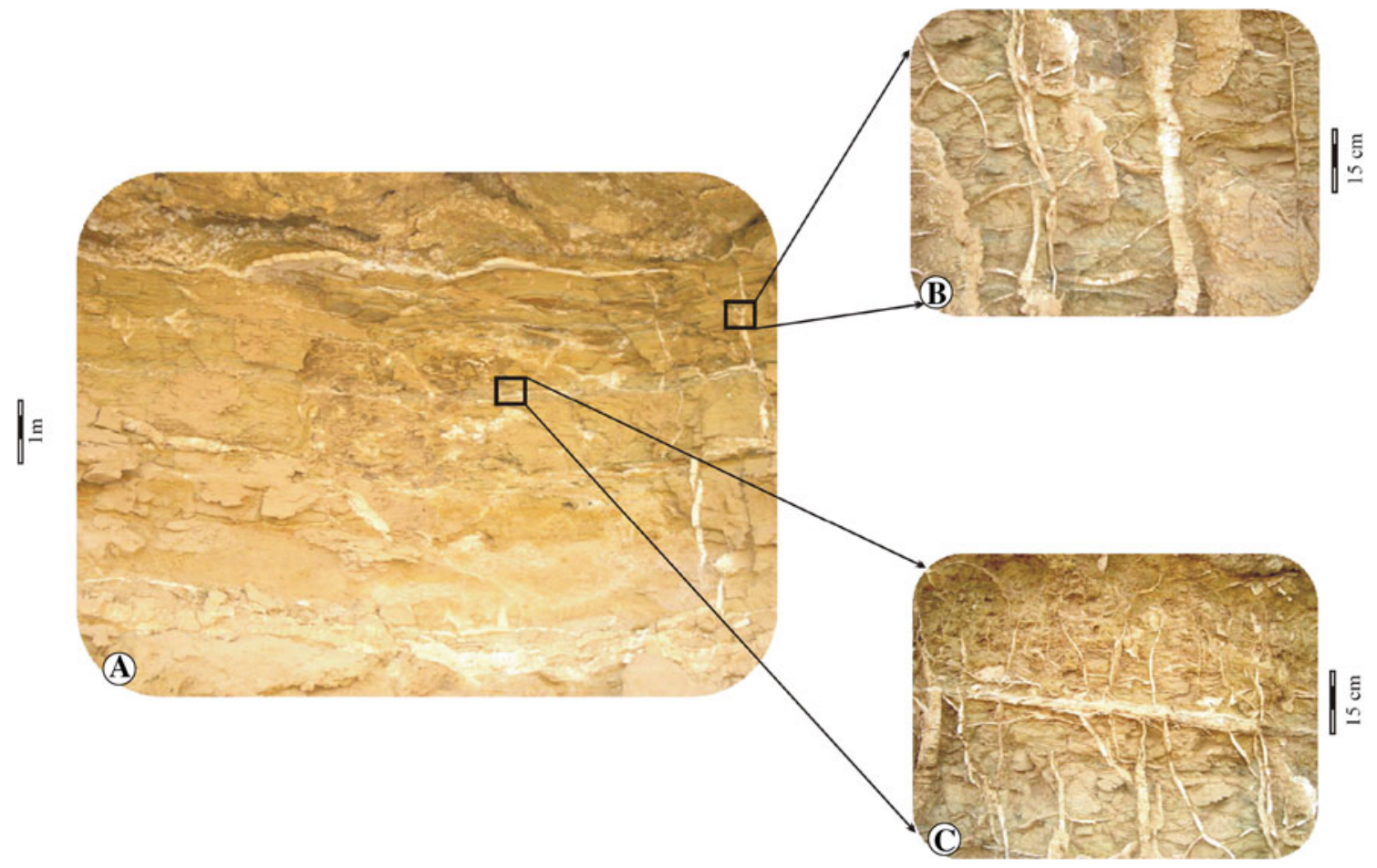

Fig. 5 a General view of the host expansive clay strata at Wadi Al-Quseir Al-Qadim (8 km north Quseir), b large vertical cracks filled with evaporite materials, $\mathbf{c}$ vertical and horizontal cracks filled with evaporite materials

Fig. 6 a X-ray diffraction pattern of Abu Dabbab Evaporite inter-bedded expansive clays. b Relative abundance of clay mineral species of Abu Dabbab Evaporite inter-bedded expansive clays
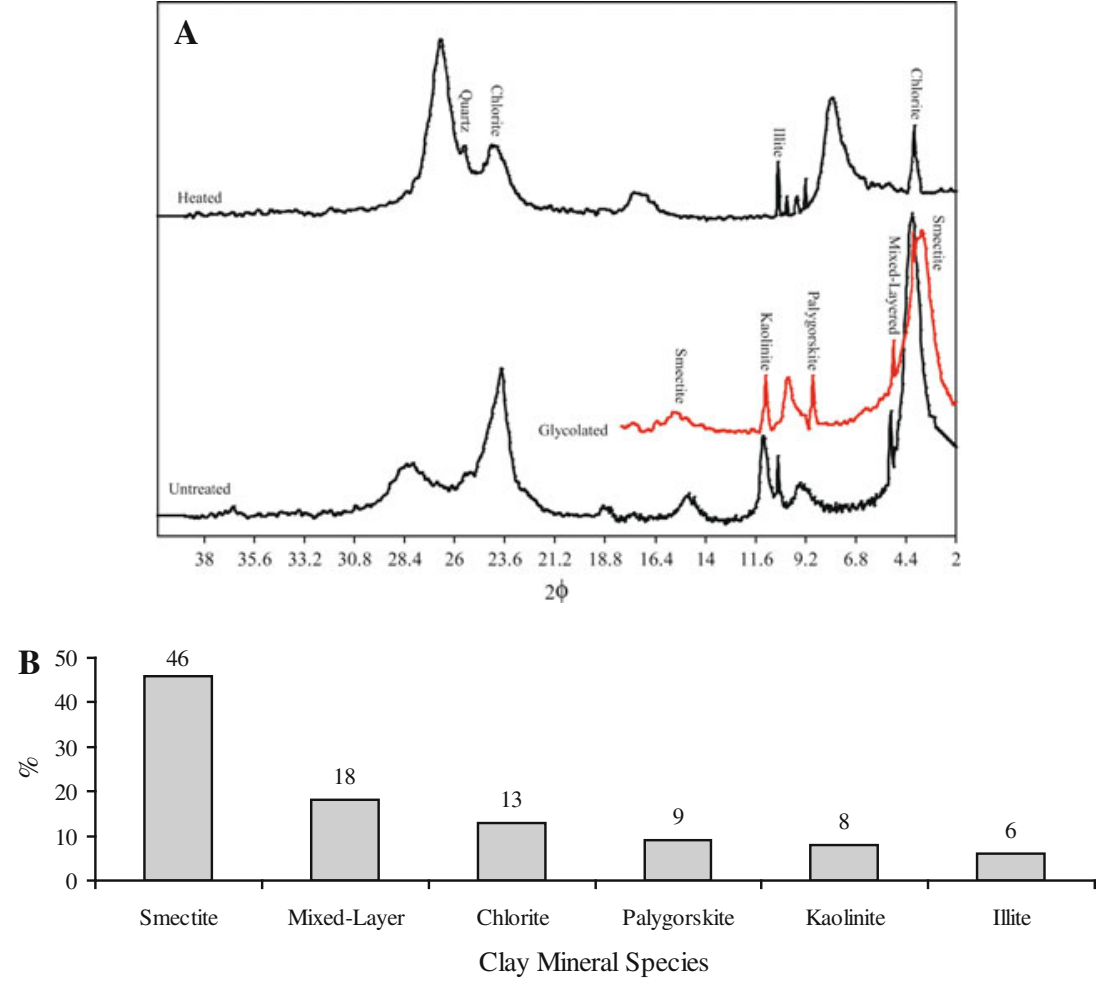

considered to have the capacity for expansive behavior [57]. [58] have proposed classifications, which give the swelling potential as a function of PI. It is generally good indica- tor of swelling potential [59], where expandable clay minerals give PI $>50$ and non-expandable types give PI values $<50$ [60]. 


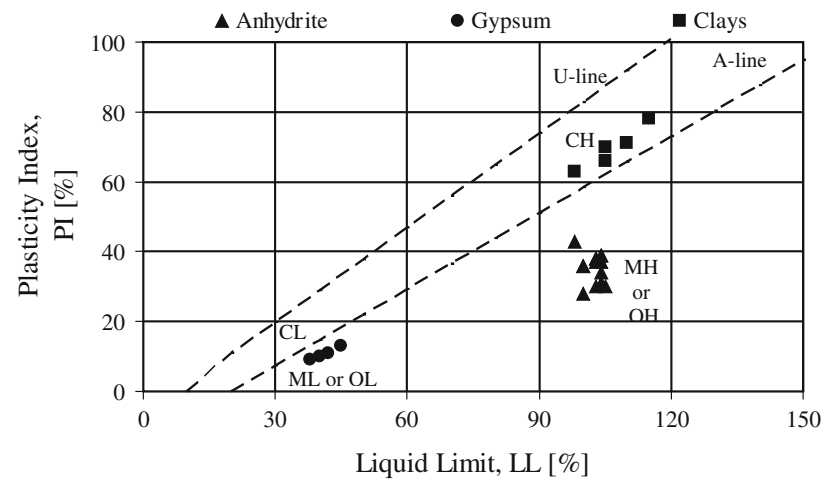

Fig. 7 Plasticity chart of the study samples

The plasticity chart (Fig. 7) shows the locations of the studied samples (anhydrite, gypsum and clays). The anhydrite and gypsum samples plot below the A-line in the fields of low (ML) and high (MH) plasticity whereas clay samples lie above the A-line in field of $(\mathrm{CH})$ high plasticity. Soils with a high content of active clay minerals, such as montmorillonite, typically plot well above the A-line [61]. The liquid limit of the study anhydrite and clays samples is higher than $65 \%$ (Table 1; Fig. 7), so these sediments are considered of very high swelling capabilities [62].

\subsection{Swelling Pressure}

Clay-sulfate rock (gypsum and anhydrite) develop considerably higher swelling pressures in swelling experiments than pure clay rocks $[63,64]$ suggesting a vital role of the transformation of anhydrite into gypsum in the swelling process of clay-sulfate rocks. Evaporitic sediments commonly contain expansible clay minerals (phyllosilicates), which have the unusual trait that their d-spacing for (001) crystal planes vary with the cation population on their exchange complex $[65,66]$. The variable spacing for a given expansible clay minerals arises from changes in the balance of expansive and contractive forces within the hydrated interlayer region of the clay mineral $[67,68]$.

Argillaceous sediments can cause heave when their moisture content increase, mainly due water adsorption. Sometimes heave may be due to the hydration of anhydrite to gypsum [69] as gypsification of anhydrite results in a volume increase of about $62 \%$ [12]. Hydration of anhydrite creates swell pressure and floor heave in dams [10]. Serious structural damage can be attributed to heaving and settlement of soils containing anhydrous calcium sulphate when they are periodically and/or differentially exposed to wetting even without a rise in the level of the ground water. Dehydration of gypsum is associated with a volume decrease of about $38 \%$ [70], which may lead to excessive settlement of the overlying structures. Furthermore, shrinkage in the gyp- sum layer and the pore pressure effects of the released water from the crystal structure of gypsum can change the state of stress within the sediments and causes significant deformation and fracturing [71].

One of the most important properties of soft and disintegrated rocks is that they have high strength in their dry state and low strength when wet. These kinds of rocks exhibit swelling behavior when they contain anhydrite and smectite group minerals such as montmorillonite. Increase in the timedependent volume of rocks containing swelling minerals like montmorillonite and anhydrite due to physico-chemical reaction with water is defined as swelling [72]. Swelling mechanism can be expressed by combination of physico-chemical reaction with water and stress relief. This reaction usually plays the most important role but swelling can only take place simultaneously with or following stress relief [73].

It is essential to have laboratory measurement of swelling characteristics on undisturbed samples for prediction the field behavior. The conventional one-dimensional odometer swell tests were performed using free axial swell. Twenty-three undisturbed representative samples (anhydrite, clay and gypsum) were chosen. The samples were prepared by cutting pieces of dimensions $6.35 \mathrm{~cm}$ diameter and $1.9 \mathrm{~cm}$ high from a hard soil block using mechanical saw machine. The samples were carefully placed in the oedometer mould. The water was allowed to imbibe at stages of saturation 5, 10, 15, 20, 25, 30, $35,40,45$ and $50 \%$ of original weight of samples and saturation state. The dial gauge records any value of swelling in these stages until the value of maximum swelling. The load $(P)$ was applied until keep it to its initial height. Swelling pressure $\left(P_{\mathrm{S}}\right)$ equal to the load $(P)$ divided by the cross sectional area $(A)$ of the sample and was calculated using the following equation:

$P_{\mathrm{S}}=\frac{P}{A}$

where:

$P_{\mathrm{S}}=$ Swelling pressure $\left(\mathrm{kg} / \mathrm{cm}^{2}\right)$

$P=$ The total load required to prevent swell of the sample $(\mathrm{kg})$

$A=$ Cross sectional area $\left(\mathrm{cm}^{2}\right)$

The swelling pressure was found to be (from 1.4 to $1.5 \mathrm{~kg} / \mathrm{cm}^{2}$ with an average value $1.45 \mathrm{~kg} / \mathrm{cm}^{2}$ ), (from 2.3 to $3.1 \mathrm{~kg} / \mathrm{cm}^{2}$ with an average value $2.69 \mathrm{~kg} / \mathrm{cm}^{2}$ ) and (from 4.7 to $5.1 \mathrm{~kg} / \mathrm{cm}^{2}$ with an average value $4.9 \mathrm{~kg} / \mathrm{cm}^{2}$ ) for gypsum, anhydrite and clay, respectively (Table 1; Fig. 8). The swelling pressure of gypsum is moderate and for both anhydrite and clay is high [74]. The swelling pressure of Abu Dabbab Evaporite samples increases with increasing anhydrite and smectite content (Table 1; Fig. 9). [75,76] have pointed out that the adsorption of water by clays leads to expansion that its magnitude varies widely depending mainly upon the kind and the amount of swelling clay minerals present. 
Fig. 8 Relationship between water content and swelling pressure
Fig. 9 Relationship between anhydrite content and swelling pressure of Abu Dabbab Evaporite
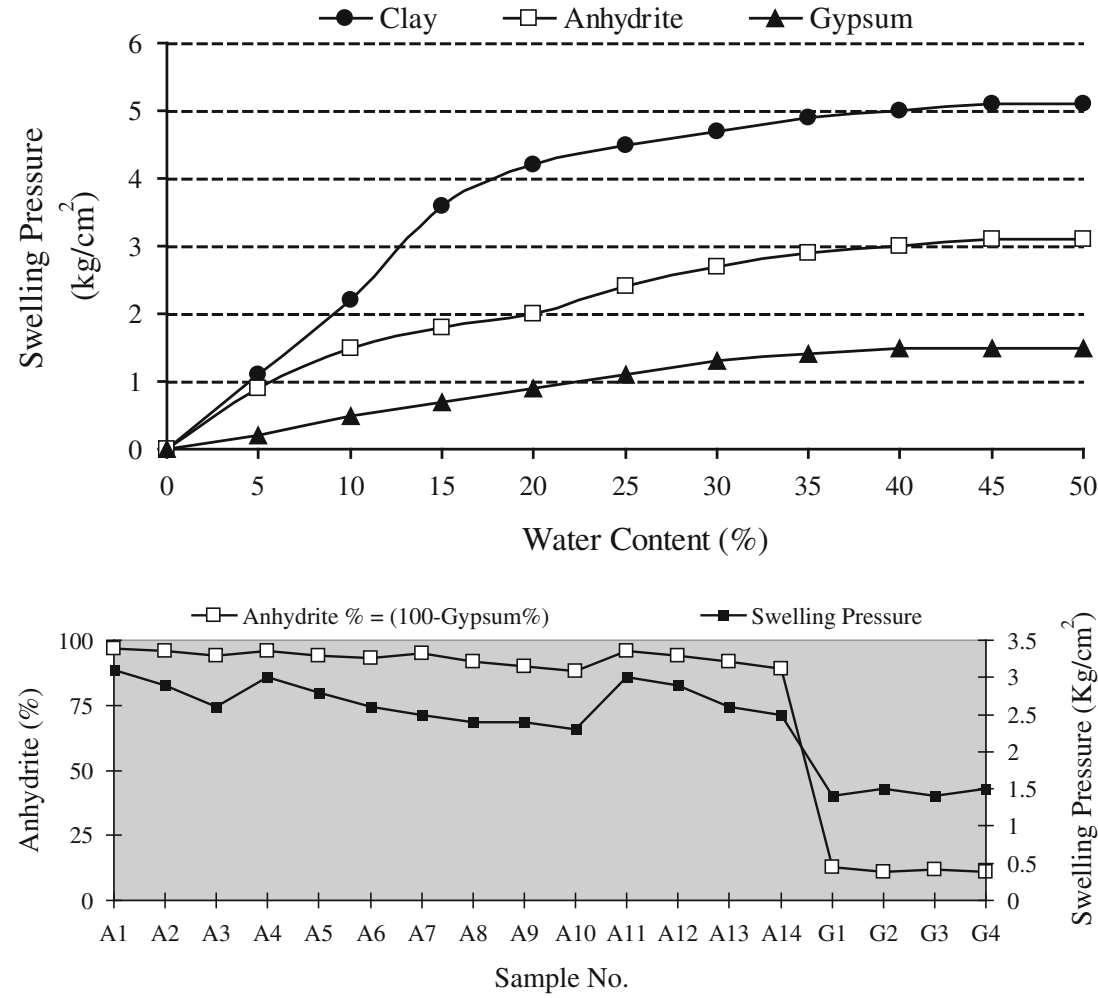

Fig. 10 Relationship between anhydrite content and swelling percent of Abu Dabbab Evaporite
The swelling ability of gypsum samples is mainly due to presence of about $12 \%$ of anhydrite within these samples, whereas the high swelling pressure of the inter-bedded clays is due to the dominance of smectite (46\%), (Table 1).

\subsection{Swell Percent}

The swelling percentage is defined as the percentage ratio between the increasing in specimen height $(\Delta H)$ under a standard stress to the initial height of specimen $\left(H_{0}\right)$. The swell percentage is calculated as follows:

$S=\frac{\Delta H}{H_{0}} \times 100$

where:

$S=$ Swelling percentage

$H_{0}=$ Initial height of the sample (mm)

$\Delta H=$ Increasing in the height of the sample (mm)
The calculated swelling percentages of the studied samples are $11-14 \%$ with an average value $12.5,28-35 \%$ with an average value 32 and 58-65\% with an average value $61.7 \%$ for gypsum, clay and anhydrite, respectively (Table 1). It is found that the swelling percent of Abu Dabbab Evaporites samples increases with increasing anhydrite and smectite content (Table 1; Fig. 10).

\subsection{Free Swelling}

The free swell test was carried out as described by [32]. A sample was dried, broken down, grinded and sieved by sieve No. $40(0.425 \mathrm{~mm})$. The material passing was again dried and poured gently to fill a $10 \mathrm{~cm}^{3}$ graduated glass cylinder. This volume of the soil was quickly poured into a $100 \mathrm{~cm}^{3}$ graduated glass cylinder filled with distilled water. The suspension was left for $24 \mathrm{~h}$. The volume of the sample was seen to increase to $\left(V_{2}\right)$. The free swell test value is given by: 
Fig. 11 Relationship between anhydrite content and free swelling (\%) of Abu Dabbab Evaporite

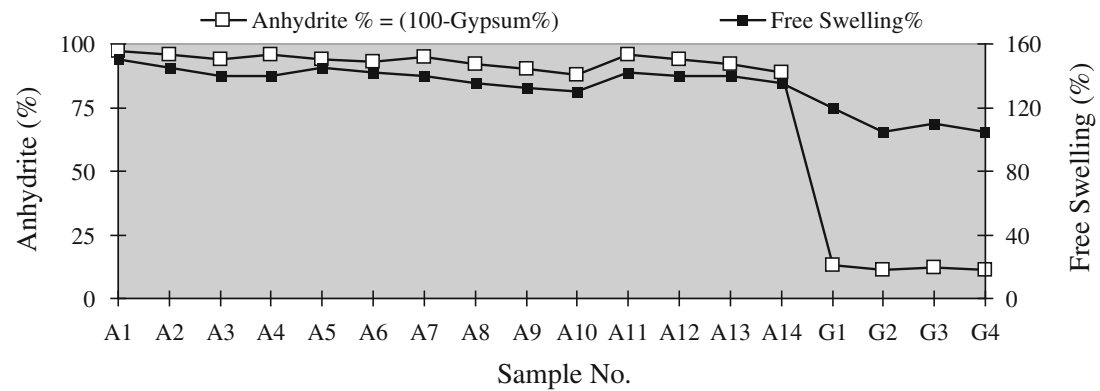

Free swelling value $(\%) \frac{V_{2}-10}{10} \times 100$

where $V_{2}$ is in $\mathrm{cm}^{3}$.

The free swelling values of the studied samples are found to be (from 150 to $165 \%$, with an average value $158 \%$ ), (from 130 to $150 \%$ with an average value $140 \%$ ) and (from 105 to $120 \%$ with an average value $110 \%$ ) for clay, anhydrite and gypsum, respectively (Table 1). The swelling potential for gypsum is moderate, while for both anhydrite and clays are critical [32]. It is clear that the free swelling of Abu Dabbab Evaporite samples increases with increasing anhydrite percent (Table 1; Fig. 11).

\section{Conclusions}

The present study is considered as a model for the effect of hydration and dehydration reaction on the mineralogical and geotechnical properties of the Middle Miocene Evaporite (Abu Dabbab Formation), Red Sea coastal region, Egypt. Experimental investigations allow reaching the following conclusions:

1. The Middle Miocene evaporite of the Abu Dabbab Formation crop out north of Quseir City along the Egyptian Red Sea Coast. It is composed mainly of anhydrite cap formed during several cycles of dehydration processes of primary gypsum under arid alkaline conditions.

2. The Abu Dabbab Evaporites are mainly composed of anhydrite (88-97\%) with subordinate gypsum (3-12\%). The lower most part near the ground surface is consisting of gypsum (87-89\%) and anhydrite (11-13\%).

3. Anhydrite exhibits chemical swelling behaviour such as clay minerals (smectite) when inundated with water. Its swelling potential has direct relationship with the anhydrite content.

4. The ability of evaporitic materials to swell depends on the amount anhydrite, which has high capability to absorb water. The hydration of anhydrite produces a chemical swelling of up to about $60 \%$.

5. The inter-bedded clays within the evaporite section consist of smectite (46\%), illite-smectite mixed-layer
(18\%), chlorite (13\%), palygorskite (9\%), kaolinite $(8 \%)$, and illite $(6 \%)$. The swelling potentials of these clays increase with increasing smectite content.

6. The geologic, geotechnical and environmental data must be integrated to define the swelling potential of this type of soil and its failure modes.

7. A sufficient safety factor must be done in the design of any construction on this type of swell-able soil.

Acknowledgments The author is deeply grateful for Editor Prof. Dr. B.M. El Ali and two anonymous reviewers for insightful comments and criticism that improved this manuscript.

Open Access This article is distributed under the terms of the Creative Commons Attribution License which permits any use, distribution, and reproduction in any medium, provided the original author(s) and the source are credited.

\section{References}

1. Chiffings, T.: Marine region 11: Arabia Seas. A global representative system of marine protected areas. http://www.deh.gov. $\mathrm{au} /$ coasts/mpa/nrsmpa/global/volume3/chapter11.html (2003). Accessed 12 Jan 2004

2. Edwards, F.J.: Climate and oceanography. In: Edwards, A., Head, SM (eds.). Key environments: The Red Sea, pp. 45-69. Pergamon, Oxford (1987)

3. Azam, S.: Study on the geological and engineering aspects of anhydrite/gypsum transition in the Arabian Gulf coastal deposits. Bull. Eng. Geol. Environ. 66(2), 177-185 (2007)

4. Wells, A.F.: Structural inorganic chemistry, 5th ed. Thetford, London (1964)

5. Deer, W.A; Howie R.A.; Zussman, J.: Rock forming minerals. Lowe and Brydon, London (1972)

6. Mitchell, J.K.; Soga, K.: Fundamentals of soil behavior, 3rd edn. Wiley, New York (2005)

7. Sonnenfeld, P.: Brines and evaporites. Academic Press Inc., Orlando, pp. 613 (1984)

8. Murray, R.C.: Origin and diagenesis of gypsum and anhydrite. J. Sediment. Petrol. 34, 512-523 (1964)

9. Bell, F.G.: Engineering geology. Blackwell, Oxford (1993)

10. Brune, G.: Anhydrite and gypsum problems in engineering geology. Eng. Geol. 2(1), 26-38 (1965)

11. Winkler, E.M.; Wilhelm, E.J.: Salt burst by hydration pressures in architectural stone in urban environments. Bull. Geol. Soc. Am. 81, 567-572 (1970)

12. Blatt, H.G.; Middleton, G.; Murray, R.: Origin of sedimentary rocks, 2nd edn. Prentice-Hall, New York, pp. 538-567 (1980) 
13. Kovári, K.; Amstad, C.; Anagnostou, G.: Design/construction methods-tunneling in swelling rocks, key questions in rock mechanics. In: Cundall et al. (eds.) Proceedings of the 29th U.S. Symposium University of Minnesota/Minneapolis, 13-15 June, Balkema (1988)

14. Kiehl, J.R.: Ein dreidimensionales Quellgesetz und seine Anwendung auf den Felshohlraum. In: Proc. 9. Nat. Felsmechanik Symposium, Aachen 1990, 185-207 (1990)

15. Wittke-Gattermann, P.: Verfahren zur Berechnung von Tunnels in quellfähigem Gebirge und Kalibrierung an einem Versuchsbauwerk. Geotechnik in Forschung und Praxis, WBI-PRINT 1. Glückauf, Essen (1998)

16. Kasprzyk, A.: Gypsum-to-anhydrite transition in the Miocene of southern Poland. J. Sediment. Res.65(2a), 348-357 (1995)

17. Azam, S.; Abduljauwadb, S.N.; Al-Shayeab, N.A.; Al-Amoudi, O.S.B.: Expansive characteristics of gypsiferous/anhydritic soil formations. Eng. Geol. 51(2), pp. 89-107 (1998)

18. Testa, G.; Lugli, S.: Gypsum-anhydrite transformations in Messinian evaporites of central Tuscany (Italy). Sediment. Geol. 130, pp. 249-268 (2000)

19. Rauh, F.; Spaun, G.; Thuro, K.: Assessment of the swelling potential of anhydrite in tunneling projects. In: Pre-Congress Proceedings 10th IAEG Congress, paper no. 473. Nottingham (2006)

20. Khalil, S.M.; McClay, K.R.: Structural control on syn-rift sedimentation, northwestern Red Sea margin, Egypt. Mar. Petrol. Geol. 26, pp. 1018-1034 (2009)

21. Akkad, S.; Dardir, A.A.: Geology of the Red Sea coast between Ras Shagra and Marsa Alam, Annual of Egyptian Geological Survey, paper No. 35. (1966)

22. Issawi, B.; Francis, M.; El-Hinnawi, M.; Mehanna, A.; El-Deftar, I.: Geology of Safaga-Quseir coastal plain and of Mohamed Rabah area. Annu. Egypt. Geol. Surv. 1, pp. 1-20 (1971)

23. El-Bassyoni, A.A.: Stratigraphic studies on Miocene and younger exposures between Quseir and Berenice, Red Sea coast, Egypt. Ph.D. Thesis, Faculty of Science, Ain-Shamis University (1982)

24. El-Haddad, A.A.: Sedimentological and geological studies on the Neogene sediments on the Egyptian part of the Red coast and the Gulf of Suez. Ph.D. thesis, Asiut University, Asiut, Egypt (1984)

25. Montenant, C.; Orsazg-Sperber, F.; Ottd Estevou, P.; Philobbos, E.R.; Purser, B.H.; Richert, J.P.: A geological study of the western edge of the Red Sea: the Ras Honkorab-Abu Ghusun area (Egypt): Documents et Travaux, IGAL (de I'Institut Gêologique Albert de Lapparent), Paris, 10, pp. 145-170 (1986)

26. Plaziat, J-C.; Montenat, C.; Orszag-Sperber, F.; Philobbos, E.; Purser, B.H.: Geodynamic significance of continental sedimentation during initiation of the NW Red Sea rift (Egypt). J. Afr. Earth Sci. 10(1-2), pp. 355-360 (1990)

27. El-Haddad, A.A.: Tectonic evaluation and diagenetic history of the Neogene Evaporites, NW Red Sea, Egypt. J. Sahar. Stud. 6, pp. $1-34$ (2007)

28. ASTM D2216: American Society for testing and materials. Test method for laboratory determination of water (moisture) content of soil and rock, ASTM section 4-construction (2005)

29. ASTM D854: American Society for testing and materials. Standard test method for specific gravity of soils, ASTM designation D85406 (2006)

30. ASTM D4318: Standard test methods for liquid Limit, plastic limit, and plasticity index of soils. ASTM designation D4318-05 (2005)

31. ASTM D2435: Standard test method for one-dimensional consolidation properties of soils, annual book of ASTM standards, ASTM International, West Conshohocken, ASTM designation D2435-04 (2004)

32. Holtz, W.G.; Gibbs, H.J.: Engineering properties of expansive clays. Trans. ASCE. 121, pp. 641-663 (1956)
33. Grim, R.E.: Clay mineralogy. McGraw-Hill Book Co., Inc., New York (1953)

34. Weaver, C.E.: Geological interpretation of clay minerals in sedimentary rock, clay minerals, 5th National Conference. Research Council Publication 566, pp. 159-175 (1958)

35. Weaver, C.E.: The distribution and identification of mixed-layer clays in sedimentary rocks. Am. J. Mineral. Soc. 41(3-4), pp. 202221 (1967)

36. Carrol, D.: Clay minerals: a guide to their $\mathrm{x}$-ray identification. Geol. Soc. Am. Spec. Paper No. 126 (1970)

37. Millot, G.: Geology of clays. Springer, New York (1970)

38. Chen, P.Y.: Table of key lines in X-ray powder identification patterns of minerals in clays and associated rocks. Occas. Indiana Geological Survey. Paper No. 21, pp. 67 (1977)

39. Wittke, W.: Rock mechanics, theory and applications with case histories. Springer, Berlin Heidelberg (1990)

40. Butler, G.P.: Modern evaporite deposition and geochemistry of coexisting brines, the sabkha, Trucial Coast, Arabian Gulf. J. Sediment. Petrol. 39, pp. 70-89 (1969)

41. Kinsman, D.J.J.: Gypsum and anhydrite of recent age, Trucial Coast, Persian Gulf. In: Proceedings of the $2^{\text {nd }}$ Symposium on Salt, vol. 1, pp 302-326. Northern Ohio Geological Society, Cleveland (1966)

42. Shearman, D.J.: Origin of marine evaporites by digenesis. Institute of Mining and Metallurgy Transactions 75(B), pp. 208-215 (1966)

43. Shearman, D.J.: Syndepositional and later diagenetic alteration of primary gypsum to anhydrite. The 6th Symposium Salt, The Salt Institute, vol. 1, pp. 44-55 (1985)

44. Hardie, L.A.: The gypsum anhydrite equilibrium at one atmosphere pressure. Am. Mineral. 62, pp. 171-200 (1967)

45. Rouchy, J.M.; Bernet-Rollande, M.C.; Maurin, A.F.: Descriptive petrography of evaporites: application in the field, subsurface, and laboratory. In: evaporitic sequences in the petroleum exploration, pp. 70-123. Technip edition, Paris (1994)

46. Kasprzyk, A.; Orti, F.: Paleogeographic and burial controls on anhydrite genesis, the Badenian basin in the Carpathian fore deep (southern Poland and Western Ukraine). Sedimentology. 45, pp. 889-907 (1998)

47. Blyth, F.G.H.; de Frietas, M.H.: A Geology for engineers, 7th edn. Butler and Tanner Limited, Frome (1984)

48. Longman, M.W.: Carbonate diagenetic textures from near-surface diagenetic environments. Am Assoc. Petrol. Geol. Bull. 64, pp. 461-487 (1980)

49. Cook, D.J.; Randazzo, A.F.; Sprinkle, C.L.: Authigenic fluorite in dolomitic rocks of the Floridan aquifer. Geology. 13, pp. 390-391 (1985)

50. Gustavson, T.C.; Hovorka, S.D.; Dutton, A.R.: Origin of satin spar veins in evaporite basins: J. Sediment. Res. A64(1), pp. 88-94 (1994)

51. Chamley, H.: Clay Sedimenyology. Springer, Berlin Heidelberg (1989)

52. Kisch, H.J.: Mineralogy and petrology of burial diagenesis and incipient metamorphism in clastic rocks. In: Larsen, G., Chilingar, G.V., (eds.) Developments in Sedimentology, vol. 25B, pp. 299493. Elsevier, New York (1983)

53. Abu Seif, E.S.: Sedimentological and mineralogical studies on the Neogene Clastic of Wadi Um Gheig-Wadi Mobarak, Red Sea, Egypt. M.Sc. Thesis, Faculty of science-South Valley University (Sohag Branch), Egypt (1999)

54. Wiersma, J.: Provenance, genesis and paleo-geographical implication of macrominerals occurring in sedimentary rocks of Jordan Valley Area. Fys.-Geogr.Bodenk. Lab. Univ., Amsterdam 15, p. 240 (1970)

55. Shadfan, H.; Dixon, J. B.: Occurrence of palygorskite in the soils and rocks of the Jordan valley: in palygorskite-sepiolite, occur- 
rences, genesis, and uses. In: Singer, A., Galan, E. (eds.), pp. 187198. Elsevier, Amsterdam (1984)

56. Yaalon, D.H.: Clays and some non-carbonate minerals in limestones and associated soils of Israel: Bull. Res. Counc. Israel. 5(B), pp. 161-173 (1955)

57. Abdullah, W.S.; Alshibli, K.A.; Al-Zou'bi, M.S.: Influence of pore water chemistry on the swelling behavior of compacted clays. Appl. Clay Sci. 15, pp. 447-462 (1999)

58. Snethen, D.R.: Evaluation of expedient methods for identification and classification of potentially expansive soils. In: 5th International Conference on Expansive Soils, Adelaide, South Australia, pp. 22-26 (1980)

59. Seed, H.G.; Woodward, R.J.Jr.; Lundgren, R.: Prediction of swelling potential for compacted clays: American Society of Civil Engineers. J. Soil Mech. Found. Div. 88(SM3), pp. 53-87 (1962)

60. Grim, R.E.: Applied clay mineralogy. MC-Graw. Hill, Book Company, Inc., New York, pp. 207-277 (1962)

61. Holtz, R.D.; Kovacs, W.D.: An introduction to geotechnical engineering: Englewood Cliffs. Prentice-Hall, New Jersey (1981)

62. Chen, F.H.: The basic physical Properties of expansive soils. In: Proceedings of 3rd International Conference on Expansive Soils. Haifa, Israel (1988)

63. Madsen, F.T.; Nüesch, R.: The swelling behaviour of clay-sulphate rocks. In: 7th International Congress on Rock Mechanics, Aachen, pp. 263-267 (1991)

64. Einstein, H.H.: Tunnelling in difficult ground—swelling behaviour and identification of swelling rocks. J. Rock Mech. Rock Eng. 29(3), pp. 113-124 (1996)

65. Barshad, I.: The effect of interlayer cations on the expansion of the mica-type crystal lattice. J. Am. Mineral. 35, pp. 225-238 (1950)

66. Mielenz, R.C.; King, M.E.: Physical-chemical properties and engineering performance of clays. Bull. Calif Div. Mines. 169, pp. 196254 (1955)
67. Walker, G.F.: On the differentiation of vermiculites and smectites in clays. Bull Clay Miner. 3, pp.154-163 (1957)

68. Grim, R.E.: Clay mineralogy, 2nd edition. McGraw-Hill, New York (1968)

69. Abduljauwad, S.N.: Swelling behaviour of calcareous clays from the Eastern Province of Saudi Arabia. Q. J. Eng. Geol. 27, pp. 333-351 (1994)

70. Zanbak, C.; Arthur, R.C.: Geochemical and engineering aspects of anhydrite/gypsum phase transitions. Bull. Assoc. Eng. Geol. 23(4), pp. 419-433 (1986)

71. Ko, S.; Olgaard D.L.; Briegel, U.: The transition from weakening to strengthening in dehydrating gypsum: evolution of excess pore pressure. Geophys. Res. Lett. 22(9), pp. 1009-1012 (1995)

72. ISRM (International Society for Rock Mechanics): characterization of swelling rock. Pergomon Press, Oxford (1983)

73. Mehmet E.B.: Swelling problems and triaxial swelling behavior of claystone: a case study in Tire, Turkey. Sci. Res. Essays 6(5), pp. 1106-1116 (2011)

74. Chen, F.H.: Foundation on expansive soil. Elsevier, Amsterdam (1975)

75. Mielenz, R.C.; Schieltz, N.C.; King, G.E.: Effects of exchangeable cation on x-ray diffraction patterns and thermal behavior of montmorillonite clay. Clays Clay Miner. 3, pp. 146-173 (1955)

76. Means, R.E.: Buildings on expansive clay. In: Theoretical and practical treatment of expansive soils: Papers and discussion from the First Soil Mechanics Conference, Colorado School of Mines, Golden, Colorado School of Mines Quarterly. 54(4) pp. 1-31 (1959) 